\title{
How do parents deal with their children's chronic kidney disease? A qualitative study for identifying factors related to parent's adaptation
}

\author{
Fatemeh Khorsandi ${ }^{1}$, Naser Parizad ${ }^{2}$ (D), Aram Feizi $^{3}$ [D and Masumeh Hemmati MaslakPak ${ }^{4,5^{*}}$ (1)
}

\begin{abstract}
Background: Parents' adaptation affects the health outcomes of children with chronic kidney diseases (CKD). Identifying factors that affect parents' adaptation is necessary to understand their adaptation status. This study aims to explore factors related to the adaptation of parents who have children with CKD.

Methods: This was a qualitative study with a content analysis approach. Seventeen parents of children with CKD were selected by using purposive sampling. The leading researcher performed semi-structured, in-depth, face-toface interviews to collect data. Conventional content analysis was used to analyze data.

Results: Two main categories extracted from the data were "adaptation facilitators" and "adaptation barriers." Adaptation facilitators were supported by three sub-categories: "social support", "family capability" and "spiritual beliefs". Four sub-categories of "adaptation barriers" were revealed as: "family-related barriers," "mental stress by others," "the chronic nature of the disease," and "unfavorable treatment conditions."

Conclusions: Identifying the factors influencing parental adaptation helps the medical staff to make the necessary interventions to support the parents. According to this study, increasing parent access to the required information, supporting them financially and emotionally, and helping them identify support resources can facilitate their adaptation to their child's chronic illness. Also, identifying and eliminating adaptation barriers can help parents deal better with their child's chronic disease.
\end{abstract}

Keywords: Adaptation, Parents, Children, Chronic kidney diseases, Qualitative study, Iran

\section{Background}

The number of children suffering from chronic diseases has increased in recent decades. It is predicted that the increasing trend will continue due to genetic and socialbehavioral changes [1]. Chronic kidney disease (CKD), with a prevalence of 18 patients in one million people, is

\footnotetext{
* Correspondence: hemmatma@yahoo.com

${ }^{4}$ Center for Mother and Child Obesity Research Center, Urmia University of Medical Sciences, Urmia, IR, Iran

${ }^{5}$ Nursing and Midwifery Faculty, Campus Nazlu, 11 KM Road Seru, Urmia, West Azerbaijan 575611-5111, Iran

Full list of author information is available at the end of the article
}

an irreversible and often progressive disease related to permanent damage to the kidney [2]. CKD threatens the lives of affected children with complications such as infections, bone diseases, low growth, and renal failure [3]. Chronic disease affects not only the child, but the family [4] including all aspects of parents' lives, such as their occupation, psychological and social health, physical and emotional health [5], and family and social relations [6]. Parents of children with CKD play a crucial role in managing their child's disease [7]. In addition to the roles of ordinary parents, these parents substitute as care

(c) The Author(s). 2020 Open Access This article is licensed under a Creative Commons Attribution 4.0 International License, which permits use, sharing, adaptation, distribution and reproduction in any medium or format, as long as you give appropriate credit to the original author(s) and the source, provide a link to the Creative Commons licence, and indicate if changes were made. The images or other third party material in this article are included in the article's Creative Commons licence, unless indicated otherwise in a credit line to the material. If material is not included in the article's Creative Commons licence and your intended use is not permitted by statutory regulation or exceeds the permitted use, you will need to obtain permission directly from the copyright holder. To view a copy of this licence, visit http://creativecommons.org/licenses/by/4.0/ The Creative Commons Public Domain Dedication waiver (http://creativecommons.org/publicdomain/zero/1.0/) applies to the data made available in this article, unless otherwise stated in a credit line to the data. 
coordinators, medical experts, systems advocates, and their children's representatives [8]. Having children with chronic diseases may lead to more significant responsibilities than ordinary parents [9].

These parents suffer from various psycho-social related stress [10]. Most of the time, they are exhausted, depressed, anxious, have a low-quality of life, and are worried about their child's future. Such intense pressure may lead to adverse effects on the child's health outcomes and their medical treatment, as well as being debilitating for the parents [11]. Thus under such circumstances, parents find it challenging to balance their unwell child's needs with their other responsibilities [12]. Therefore, such parents are sometimes called hidden patients [13]. These parents apply adaptation strategies to reduce tension and anxiety and adapt to their new conditions to react to the family's stressful situations, deal with difficult situations, and maintain the whole family's performance $[14,15]$.

Parents' adaptation indicates a process by which a family manages the needs related to disease control based on available resources. Parents who are poorly adapted to their child's illness may be involved in their children's distress [8]. Due to the lack of adaptation, the child and their family are exposed to upcoming unpleasant consequences. These consequences may include mental health problems, low family quality of life, marital conflict, and negative effects on the child and their siblings [16]. Various factors are involved in the parents' adaptation to their child's chronic illness [17]. These factors must be identified in order to understand parents' adaptation status [18]. Considering the influence of parents' adaptation on the overall health outcome of children with chronic diseases [19], the medical team must help the family adapt to the new care situations and emotional problems associated with it [18]. However, this support is not fully implemented for these families [17].

Moreover, research regarding caregivers of chronic patients' adaptation is limited, and the focus is more on quantitative studies than the experiences of caregivers [20]. Qualitative research is the appropriate method to access individuals' lived experience and their inner world. A qualitative study can also help clarify the ambiguous and unknown phenomenon [21]. Since the parents' adaptation and related factors are a vague and unknown phenomenon, this study was conducted to explore factors related to the adaptation of parents who have children with CKD.

\section{Methods}

\section{Study design and setting}

We used a qualitative study with a content analysis approach to explore parent experience and gain a more profound understanding of the factors that influence their adaptation. This study was conducted in Shahid Motahari pediatric hospital of Urmia in Iran.

\section{Participants}

Participants were parents of children with CKD who were admitted to the nephrology department. We used purposive sampling to recruit the participants. First, we referred to the nephrology department and selected parents who were eligible to enter the study. Then, we conducted an informal face-to-face conversation to assess the parent's ability to express experiences. After viewing the parents' ability to express experiences, we explained the study's purpose and process, their role in the study, and the confidentiality of the information. We also notified them that they could leave the study at any time. Then, we obtained verbal and written consent and asked permission to record the interview. Next, we invited parents to the study and determined the time and place of interview based on their convenience. We conducted all the interviews in a private, familiar and quiet room in the nephrology department after visiting hours. In those hours, doctors' visits and nursing care were completed, and family visiting hours were usually finished. We invited 17 parents to participate in the study. None of the invited parents declined our invitation. Thus, 17 parents of 15 children with CKD were recruited to participate in the study. Inclusion criteria were the willingness to participate in the study, the ability of parents to express experiences, not being a single parent, more than six months passed since the child's diagnosis and finally, parents not having a mental illness.

\section{Data collection}

The leading researcher performed data collection by using interviews and field notes from September 2018 to September 2019. She had passed six credit hours of qualitative research methodology before performing the interviews. She worked in the Nephrology unit in the pediatric hospital. She was interested in the study topic and performed the interviews after obtaining permission from the parents. Semi-structured, in-depth, and faceto-face interviews were conducted. Before starting the formal interview, she briefly spoke with the participant about everyday issues to create a friendly atmosphere and a sense of comfort for the participant to express their experiences. After participants completed the demographic questionnaires, the interview began with a general and open-ended question, followed by probing questions based on the parents' responses. She used a previous similar study to guide the first interviews [22]. She began with general open-ended questions, including "How did you deal with your child's illness?" Based on the participants' answers, probing questions were asked to obtain a complete understanding of their experiences. 
The probing questions included "What do you mean by that?" or "would you please explain more about that?" There was no need to repeat any of the interviews. The interviews lasted for 20 to $100 \mathrm{~min}$, with an average of $37.76 \mathrm{~min}$. Each interview was digitally recorded, transcribed, and analyzed after it is conducted. The process continued until data saturation was achieved, which indicated that no new additional concepts were identified [23].

\section{Data analysis}

Data were analyzed using MAXQDA10 software. A conventional six-step content analysis [24] was used to analyze data and including:

1. reaching a general understanding by immersion and reading the transcription several times to detect primary ideas

2. creating primary codes in the transcription by rereading line by line

3. searching for and determining categories and subcategories

4. reviewing and discovering the relationship between categories and sub-categories

5. labeling and describing the categories and subcategories

6. interpreting and presenting the final report of the analysis.

The leading author performed the data analysis, and the other authors participated and monitored the coding process. The research team had several meetings and discussions before reaching an agreement on the coding and categorization. We used the COREQ checklist to improve quality reporting in this study (see supplementary files).

\section{Rigor}

Guba and Lincoln's criteria were used to ensure the precision and accuracy of the data [25]. The data's credibility increased through prolonged engagement with the data and reviewing data with experts and the participants. Conformability was achieved by careful recording and precise reporting of the research process and findings. It was also attempted to prevent the researcher's bias during data collection and data analysis. The entire study was recorded carefully with step by step repetition and audit performed to confirm dependability. To obtain transferability, external reviewers precisely reviewed and confirmed the data.

\section{Results}

Demographic characteristics of the participants

Of all 17 parents who participated in the study, 11 were mothers, and 6 were fathers. Seven parents had one child, nine had two children, and one had three children. The duration of childhood illness was between 7 and 144 months $(60.47 \pm 44.03)$. Four parents had primary education, three parents had a middle school education, seven parents had a high school diploma, and three had a bachelor's degree. Of the children's diseases, nine cases were nephrotic syndrome; two were chronic renal failure, one was secondary to Familial Mediterranean fever (FMF), one case was secondary to Cystinosis, one was severe fetal hydronephrosis secondary to kidney stones, and one was neurogenic bladder (Table 1).

\section{Categories}

"Adaptation facilitators" and "adaptation barriers" emerged as two overarching categories from the data. Adaptation facilitator, followed by three sub-categories of "social support," "family capability," and "spiritual beliefs." Adaptation barriers were supported by the following four sub-categories: "family-related barriers," "mental stress by others," "the chronic nature of the disease" and "unfavorable treatment conditions." (Tables 2 and 3). (See Fig. 1).

\section{Adaptation facilitators \\ Social support}

The participants emphasized this item as one of the significant factors that help them adapt to hard situations. The following primary concepts emerged from this subcategory: "hospital personnel assistance," "family support," "school personnel assistance," and "support of colleagues."

\section{Hospital personnel assistance}

Some parents talked about how the guidance and education they received from the nurses, doctors and resources increased their knowledge. This education, in turn, enabled them to provide high-quality care for their child with a more peaceful mind. Some of the participants stated:

“... The nurses here give us a lot of consolation. Whenever I cried, they came in and talked to me about the other patients' situations and gave me encouragement" [p9].

"At the time of discharge, the doctor explained everything so nicely. He gave me the instruction, how to give his (my son) medications, how long I should give his medications, and when he should stop taking them ..." [p1].

\section{Family support}

Parents voiced that caring for their children with the chronic disease made them feel exhausted. In such 
Table 1 Demographic characteristics of participants

\begin{tabular}{|c|c|c|c|c|c|c|c|c|}
\hline No. & Gender & $\begin{array}{l}\text { Number of } \\
\text { Children }\end{array}$ & $\begin{array}{l}\text { Children's } \\
\text { illness } \\
\text { duration }\end{array}$ & $\begin{array}{l}\text { Parents } \\
\text { Education } \\
\text { level }\end{array}$ & $\begin{array}{l}\text { Interview } \\
\text { duration }\end{array}$ & Job status & Children Diagnosis & Children Treatment \\
\hline 1 & Female & 2 & 5 years & $\begin{array}{l}\text { High school } \\
\text { Diploma }\end{array}$ & 37 & Housewife & Renal failure secondary to FMF & $\begin{array}{l}\text { Conservative } \\
\text { treatment }\end{array}$ \\
\hline 2 & Female & 2 & 2 years & $\begin{array}{l}\text { Primary } \\
\text { education }\end{array}$ & 60 & Unemployed & $\begin{array}{l}\text { Severe fetal hydronephrosis } \\
\text { secondary to kidney stones }\end{array}$ & $\begin{array}{l}\text { Surgery \& } \\
\text { conservative } \\
\text { treatment }\end{array}$ \\
\hline 3 & Male & 2 & 7 years & Middle school & 41 & $\begin{array}{l}\text { Self- } \\
\text { employment }\end{array}$ & Nephrotic syndrome & $\begin{array}{l}\text { Conservative } \\
\text { treatment }\end{array}$ \\
\hline 4 & Female & 1 & 4 years & $\begin{array}{l}\text { Primary } \\
\text { education }\end{array}$ & 24 & Housewife & Neurogenic bladder & $\begin{array}{l}\text { Clean intermittent } \\
\text { catheterization }(\mathrm{CIC})\end{array}$ \\
\hline 5 & Male & 2 & 5 years & $\begin{array}{l}\text { High school } \\
\text { Diploma }\end{array}$ & 30 & $\begin{array}{l}\text { Self- } \\
\text { employment }\end{array}$ & Husband of Participants 1 & \\
\hline 6 & Female & 1 & 12 years & $\begin{array}{l}\text { High school } \\
\text { Diploma }\end{array}$ & 33 & $\begin{array}{l}\text { Self- } \\
\text { employment }\end{array}$ & Nephrotic syndrome & $\begin{array}{l}\text { conservative } \\
\text { treatment }\end{array}$ \\
\hline 7 & Male & 1 & 11 years & $\begin{array}{l}\text { Bachelor's } \\
\text { degree }\end{array}$ & 60 & Employee & Chronic Renal Failure & $\begin{array}{l}\text { Peritoneal Dialysis, } \\
\text { transplanted }\end{array}$ \\
\hline 8 & Male & 2 & 7 years & $\begin{array}{l}\text { High school } \\
\text { Diploma }\end{array}$ & 20 & $\begin{array}{l}\text { Self- } \\
\text { employment }\end{array}$ & Nephrotic syndrome & Peritoneal Dialysis \\
\hline 9 & Female & 1 & 2 years & $\begin{array}{l}\text { Primary } \\
\text { education }\end{array}$ & 24 & housewife & Chronic Renal Failure & Peritoneal Dialysis \\
\hline 10 & Female & 2 & 2 years & $\begin{array}{l}\text { High school } \\
\text { Diploma }\end{array}$ & 40 & Housewife & Nephrotic syndrome & $\begin{array}{l}\text { Conservative } \\
\text { treatment }\end{array}$ \\
\hline 11 & Female & 2 & 3 years & $\begin{array}{l}\text { Bachelor's } \\
\text { degree }\end{array}$ & 25 & Housewife & Nephrotic syndrome & $\begin{array}{l}\text { Conservative } \\
\text { treatment }\end{array}$ \\
\hline 12 & Male & 2 & 2 years & $\begin{array}{l}\text { High school } \\
\text { Diploma }\end{array}$ & 41 & Unemployed & Husband of Participants 10 & \\
\hline 13 & Male & 1 & 7 months & Middle school & 35 & Worker & $\begin{array}{l}\text { Renal failure secondary to } \\
\text { Cystinosis }\end{array}$ & $\begin{array}{l}\text { Conservative } \\
\text { treatment }\end{array}$ \\
\hline 14 & Female & 2 & 2 years & Middle school & 20 & Housewife & Nephrotic syndrome & $\begin{array}{l}\text { Conservative } \\
\text { treatment }\end{array}$ \\
\hline 15 & Female & 3 & 10 years & $\begin{array}{l}\text { Primary } \\
\text { education }\end{array}$ & 100 & Housewife & Nephrotic syndrome & $\begin{array}{l}\text { Conservative } \\
\text { treatment }\end{array}$ \\
\hline 16 & Female & 1 & 3 years & $\begin{array}{l}\text { Bachelor's } \\
\text { degree }\end{array}$ & 30 & $\begin{array}{l}\text { Self- } \\
\text { employment }\end{array}$ & Nephrotic syndrome & $\begin{array}{l}\text { Conservative } \\
\text { treatment }\end{array}$ \\
\hline 17 & Female & 1 & 4 years & $\begin{array}{l}\text { High school } \\
\text { Diploma }\end{array}$ & 35 & Housewife & Nephrotic syndrome & $\begin{array}{l}\text { Conservative } \\
\text { treatment }\end{array}$ \\
\hline
\end{tabular}

circumstances, their family's support made it easier for them to go through. This support was either emotional or financial. Some of the participants' experience was as follows:

“... His treatment costs 180 million Rials the last time he was in the hospital. Can you believe that? I didn't even have one Rial. My brothers paid it off." [p7].

“... My husband is always supportive. He helps me by taking care of the kids. He takes them to the doctor, brings them back ..." [p10].

\section{School personnel assistance}

Some of the parents discussed how teachers or principals helped their children during their acute illness.
Teachers went to their homes to teach them so that they would not miss their lessons. One of the parents said:

"... Because of his disease, he is absent everyday ... even his principle comes to our home to teach him" [p7].

\section{Support of colleagues}

Some parents mentioned their colleagues' assistants and how supportive they were whenever facing difficult situations. One of the parents stated:

“... At work also, the burden is on my colleague. Sometimes, I am out for one or two days. My colleagues help me out and cover for me ..." [p8]. 
Table 2 Categories, sub-categories, and primeary concepts of the study

\begin{tabular}{|c|c|c|}
\hline Categories & Sub-categories & Primary concepts \\
\hline \multirow[t]{3}{*}{ Adaptation facilitators } & Social support & $\begin{array}{l}\text { * Hospital personnel assistance } \\
\text { * Family Support } \\
\text { * School personnel assistance } \\
\text { * Support of colleagues }\end{array}$ \\
\hline & Family capability & $\begin{array}{l}\text { * Parents financial ability } \\
\text { * Child's educational success } \\
\text { * Good relationships between parents } \\
\text { * Parents similar past experiences }\end{array}$ \\
\hline & Spiritual beliefs & $\begin{array}{l}\text { * Appealing to God } \\
\text { * Divine wisdom }\end{array}$ \\
\hline \multirow[t]{4}{*}{ Adaptation barriers } & Family-related barriers & $\begin{array}{l}\text { * Lack of parents' information about illness } \\
\text { * Parents' concern about uncertain future } \\
\text { * Families' financial concerns } \\
\text { * Restrictions in family recreation } \\
\text { * Restrictions on family relationships } \\
\text { * Children's problems }\end{array}$ \\
\hline & Mental stress by others & $\begin{array}{l}\text { * Pity from acquaintances } \\
\text { * Blaming parents by acquaintances } \\
\text { * Peer negative reactions }\end{array}$ \\
\hline & The chronic nature of the disease & $\begin{array}{l}\text { * Frequent disease recurrence } \\
\text { * Frequent hospitalizations } \\
\text { * Need for constant care } \\
\text { * Invasive treatment and diagnostic procedures }\end{array}$ \\
\hline & Unfavorable treatment conditions & $\begin{array}{l}\text { * Lack of medical facilities } \\
\text { * High treatment costs }\end{array}$ \\
\hline
\end{tabular}

\section{Family capability}

Family capability is one of the adaptation facilitators that parents repeatedly talked about. The primary concepts related to this sub-category include: "parents' financial ability," "child's educational success," "good relationships between parents," and "parents' similar past experiences."

\section{Parents' financial ability}

Participants mentioned that some factors, such as their financial ability, made it easier for them to tolerate their child's disease. A father voiced:

"If you have a sick child and you are broke, it would be a disaster and unbearable. But, luckily, I didn't have any financial problems in the past 11 years ..." [p7].

\section{Child's educational success}

Another comforting factor for parents was a child's good education status. Participant 11 stated:

"He is a good student. I take him to school once a month. He takes his exams. Teachers say his grades are excellent." [p11].

\section{Good relationships between parents}

According to the participants, another supportive factor for parents was their happy and peaceful relationship during this overwhelming and challenging situation. One parent stated:

“... Despite all these difficulties, we (my husband and I) love each other. So, we've gone through all these problems ..." [p4].

\section{Parents similar past experiences}

Analyzing parents' experiences indicate that the ups and downs of life have improved parents' tolerance and made them more capable of managing their child's disease.

"My father was also on dialysis. I already had the experience of caring for a patient with kidney problems. It's hard, but you get used to it" [p9].

\section{Spiritual beliefs}

Spiritual beliefs were another facilitating factor that effectively helped parents get along with their child's disease. Parents believed "appealing to God" and "divine wisdom" helped them to tolerate the hard situation.

\section{Appealing to god}

Participants discussed that faith and belief in God have brought them tranquility and increased their ability to handle their problems. A mother stated: 
Table 3 Categories, subcategories, primary concepts and quotations of the study

\section{Categories Subcategories}

Adaptation Social support

facilitators

\section{Primary concepts \\ * Hospital personnel assistance}

* Family Support

* School personnel assistance

* Support of colleagues

Family capability

* Parents financial ability

* Child's educational success

* Good relationships between parents

* Parents similar past experiences

Spiritual beliefs

* Appealing to God

* Divine wisdom

* Lack of parents' information about illness

* Parents' concern about uncertain future

* Families' financial concerns

* Restrictions in family recreation

\section{Quotation}

"Nurses here are so sweet. They explain everything to me. You have to wash your and your sons' hands more often. Whenever you come to the hall, you have to wear a mask. Your son should not go out at all in the fall and winter" [p15].

"... The nurses here give us a lot of consolation. Whenever I cried, they came in and talked to me about the other patients' situations and gave me encouragement" [p9].

"If I need help, I always ask my mom to come and help me. For example, she comes and helps me with household chores" [p15].

"... My husband is always supportive. He helps me by taking care of the kids. He takes them to the doctor, brings them back ..." [p10].

"When my son is in the hospital, his teacher comes by to teach him" [p5].

"... Because of his disease, he is absent everyday ... even his principle comes home to teach him" [p7].

"Fortunately, my boss is very cooperative. Once, when my son was hospitalized in Tehran, he agreed to give me off, and I was out of work for 40 days" [p7].

"... At work also, the burden is on my colleague. Sometimes, I am out for one or two days. My colleagues help me out and cover for me ..." [p8]

"I always thank God, we don't have a financial problem. I can not imagine what we should do if we don't have money to take care of our sick child!!! May God help those who do not effort medications and treatment costs" [p1].

"If you have a sick kid and also you are broke, it would be a disaster and unbearable. But, luckily, I didn't have any financial problem in the past 11 years ..." [p7].

"Although he is sometimes hospitalized and cannot go to school, his grades are good, and teachers are happy with him" [p4].

"He is a good student. I take him to school once a month. He takes his exams. Teachers say his grades are excellent" [p11].

"My husband is like a pillar for our family. He always pays attention to me, he doesn't let me down" [p10].

"... Despite all these difficulties, we (my husband and me) love each other. So, we've gone through all these problems ..." [p4].

"My first kid has the same problem. I got used to the situation. I don't take him to the doctor's office for little things. I know what I have to do when my kids get sick" [p2].

My father was also on dialysis. I already had the experience of caring for a patient with kidney problems. It's hard, but you get used to it" [p9].

"My wife and I always pray to God in a hard time. Whenever we do that, we get energy" [p12].

"He (My husband) always told me to keep your faith up and let God take over our problems during hard times... Sometimes, he had huge problems in his life, but he believed that he's backed by God. So his problems will go away and this has always been happening" [p1].

"This disease is from God, not human beings. Treatment is also on his hands and doctors are as tools in his hand. What can we do?" [p11].

"I say this is a divine test. I always say: God tests his servants with difficulties ..." [p10].

"We don't know what all these medications are for. Where should we buy them? How should we give?" [p13].

"I don't know anything about peritoneal dialysis ... Creatinine increased up to 6. The doctor said he was on a razor edge, he should go for peritoneal dialysis. The only thing I knew about dialysis was this catheter that they enter from here (pointing to the neck); I said if my son had that (catheter), I couldn't live anymore" [p7].

"When will this kid be well? How long should he take these medications? Is he going to get better? ..." [p10].

"I really worry about his future all the time. I always ask (myself) whether he will get well when he grows up. Parents don't stay with them (children) forever ..." [p11].

"My son is hospitalized more often, and we have to leave home and bring him here. When he is in the hospital, my husband stays in the hospital yard all night because we can't effort to pay for the hotel" [p1].

"Sometimes, I have to borrow from my family to get her medications. Things are getting really tough" [16].

"I don't let my other child go to the park or play somewhere. Because whenever he goes out to play with his friends. He asks me why I don't go out to play. That's why 
Table 3 Categories, subcategories, primary concepts and quotations of the study (Continued)

\section{Categories Subcategories Primary concepts}

* Restrictions on family relationships

* Children's problems

Mental stress by others

The chronic nature ${ }^{*}$ Frequent disease of the disease

Unfavorable treatment conditions

* Pity from acquaintances

* Blaming parents by acquaintances

* Peer negative reactions
* Frequent hospitalizations

Need for constant care

* Invasive treatment and diagnostic procedures

\section{Quotation}

they both stay at home" [p11].

"Everybody likes to go and enjoy parties or trips, but ... these children take corticosteroids, their body is sensitive ... so we can't go out much ..." [p10].

"My son is 8 years old and he is still on a diaper. So, I try to limit the family visits" [p7].

"I don't go anywhere because of my kid. I live in my mother-in-laws house. They usually go out and attend ceremonies... But, I stay home to take care of my kid" [p11].

"Ever since my daughter has been using prednisolone. She gets nervous when the house gets crowded, or there is a lot of noise around her" [p6].

"His teacher told me that your son is a little depressed. I asked him what is wrong. He said, leave me alone. Everyone eats puffy cheese and chips, but I can't ... "[p15]. "My son doesn't go to school. He went to school once; he had eaten ice cream with his friends. Then, he was hospitalized for 1 year ... so we hired a teacher to teach him at home ..." [p11].

"Every time my co-worker talks about my daughter with pity, I get agitated" [p6]. "Some people say: "oh, this (child) is sick; don't tell him anything!" ... It really pisses me off, and I tell them, "what's wrong with him? Every kid gets sick..." [p10].

"My friends blame me that my daughter would not get sick if I did not marry this man" [p6].

"My mother-in-law always says it is our fault (my husband and me) that he's sick. Crying is the only thing I do and ask what I should do?" [p9].

"One day, my son came home crying. I said, "Darling, why are you crying?" He told me that his friends did not let him play. They said he can't play because he has cancer" [p5].

"... Taking corticosteroids made her (my daughter) obese... Sometimes, her friends make fun of her, it really bothers me ..." [p8]

"This is the third time my son is taking this medication ... he had stopped two months ago. He has to start again because of its recurrence" [p12].

"... She takes corticosteroids every day. Her disease gets better for a while. Later, when we try to decrease and stop her medications gradually, again, her disease gets worse ..." [p8].

"My son has been hospitalized about 20 times so far. We both are sick and tired of being in the hospital" [p10].

"It's been passed seven years since my daughter's illness. During this time, I had to hospitalize her again and again" [p3].

"When my son discharged home. The nurse taught my wife how to do Peritoneal Dialysis. We have to dialyze him regularly. We should pay attention to the fluid coming back from dialysis. I feel so stressed out sometimes" [p7].

"His school is far from home. I have a hard time. When he is at school, I have to go to school every $3 \mathrm{~h}$ and insert his catheter ..." [p4].

"I always thought my daughter would be treated with medications ... but when I found out, they had to take her to the operating room and put a catheter in her abdomen (peritoneal dialysis catheter) ... I had a hard time breathing [p8]. "The doctor told me, "Your kid needs to have a biopsy." I said, "What does that mean?"He said that they should take a sample from his kidney. When I heard that my world came apart" [p15]

* Lack of medical facilities "Doctor told me your son needs a color biopsy, and we don't have it here. You must go to Tehran. I was so depressed" [p5].

"The boy (transplantation donor) had come from Tehran for pre-surgical anesthesia assessment. So that, he supposed to get a consultation on Tuesday, hospitalize on Thursday, and go under the surgery on Saturday. He (laboratory director) said, unfortunately, the solution (necessary for tissue typing test) was not available. I asked what that is. He said the (required) material for this test came from Germany. It is not available now. [p7].

* High treatment costs "If it was just the medications costs, we wouldn't have any problem. I took my son to a nutritionist and cost me too much money" [p13].

"During these years, sometimes my son had been hospitalized for a month. Well, it cost us too much money, and we had a hard time to survive" [p10]. 


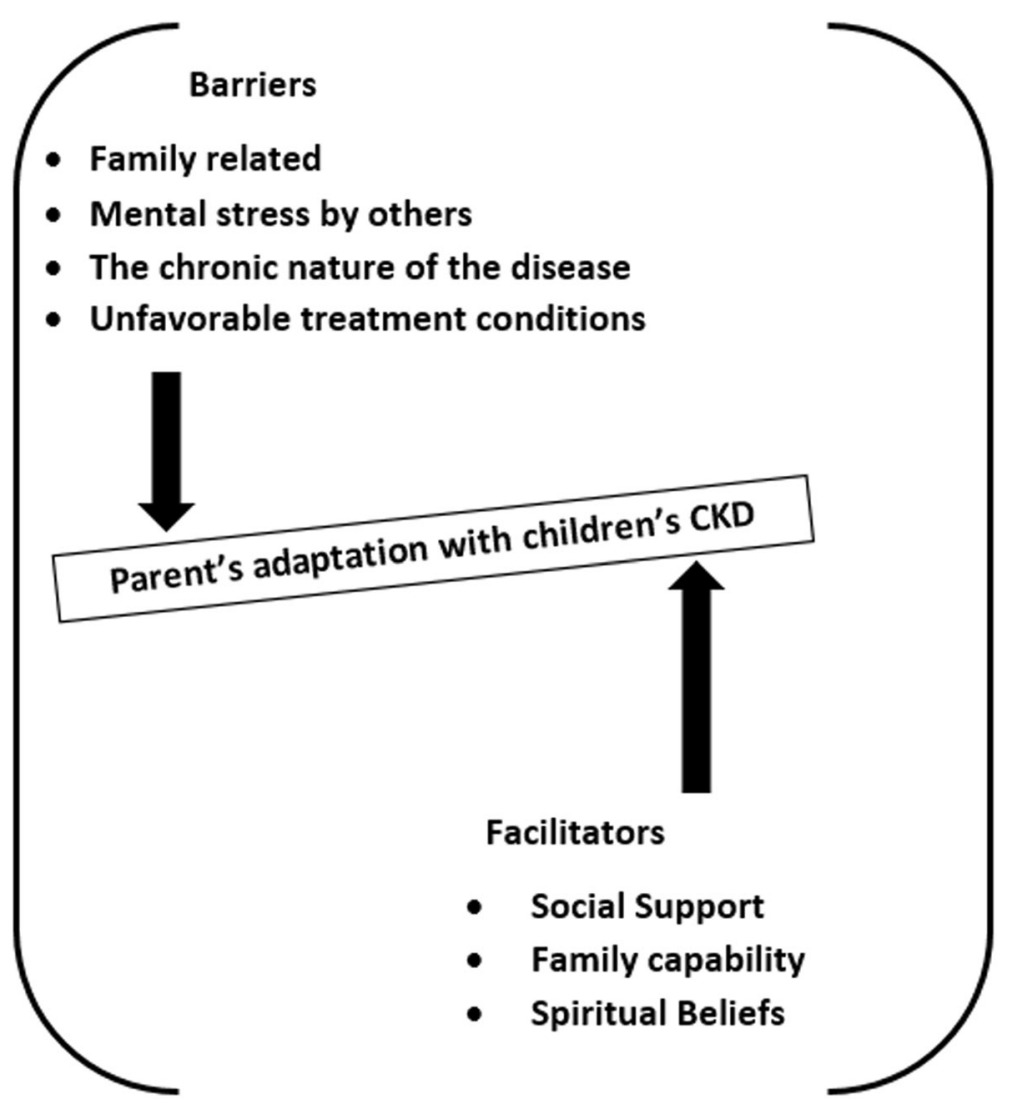

Fig. 1 Schematic model of factors influencing parents' adaptation

"He (My husband) always told me to keep your faith up and let God take over our problems during hard times ... Sometimes, he had huge problems in his life, but he believed that God backed him. So his problems will go away, and this has always been happening" [p1].

\section{Divine wisdom}

Participants mentioned that life's difficulties have been for a divine reason and described their child's disease as God's test. Parents shared their experience as follows:

"I say this is a divine test. I always say: God tests his servants with difficulties ..." [p10].

"This disease is from God, not human beings. Treatment is also on his hands, and doctors are tools in his hand. What can we do?" [p11].

\section{Adaptation barriers}

\section{Family-related barriers}

This sub-category contained the primary concepts of "lack of parents' information about the illness," "parents' concern about the uncertain future," "families' financial concerns," "restriction in family recreation," "restrictions on family relationships" and "children's problems."

\section{Lack of parents' information about the illness}

Based on statements by the participants, the lack of necessary information about their child's disease, and how to care for their sick child made them confused. One participant voiced:

"I don't know anything about peritoneal dialysis ... Creatinine increased up to 6. The doctor said he was on a razor's edge; he should go for peritoneal dialysis. The only thing I knew about dialysis was this catheter that they enter from here (pointing to the neck); I said if my son had that (catheter), I couldn't live anymore." [p7].

\section{Parents' concern about the uncertain future}

According to the participants, the uncertain nature of the disease and the uncertainty of the child's prognosis made the parents feel concerned about their child's future. A mother voiced her concern as follows:

"I really worry about his future all the time. I always ask (myself) whether he will get well when he grows 
up. Parents don't stay with them (children) forever ..." [p11].

\section{Families' financial concerns}

Families' financial problems were dominant in the parents' interviews. Most parents complained about financial difficulties. Participant 4 voiced:

"My son is hospitalized more often, and we have to leave home and bring him here. When he is in the hospital, my husband stays in the hospital yard all night because we can't afford to pay for the hotel." [p1].

\section{Restrictions in family recreation}

The majority of the participants explained that they restricted their recreational activities and family trips due to their child's limitations for attending social events due to weakness of their immune system. One parent shared her experience as:

"Everybody likes to go and enjoy parties or trips, but ... these children take corticosteroids, and their body is sensitive ... so we can't go out much ..." [p10].

\section{Restrictions on family relationships}

Participants expressed that they had to limit their social interactions due to their child's special diet and disease complications.

"I don't go anywhere because of my kid. I live in my mother-in-law's house. They usually go out and attend ceremonies ... But, I stay home to take care of my kid." [p11].

\section{Children's problem}

Participants described that the disease, its complications, and the medications' side-effects limit children in their normal functions and daily activities, thus disrupting their social growth.

“My son doesn't go to school. He went to school once; he had eaten ice cream with his friends. Then, he was hospitalized for one year ... so we hired a teacher to teach him at home ..." [p11].

According to the parents, the feeling of being special and different from other children, hearing hallucinations, yearning, being bored, fear of loneliness, depression, and irritability are among the mental health problems. Moreover, repeated infections, rapid fatigue, and anemia are among the physical health problems that these children suffer from. Parents described:
"... My daughter suffers from too much hair all over her body. She's gained weight, and so she feels socially awkward ..." [p8].

"... They constantly inserted a catheter for my child. She couldn't pee herself, so she repeatedly got urinary tract infections ..." [p16].

\section{Mental stress by others}

The parents discussed pressure from acquaintances. They voiced that it is hard to withstand their pity and blame. The inappropriate behaviors of their child's peers made it even more difficult to handle the situation.

\section{Pity from acquaintances}

Most parents experienced people talking about their sick children. They believed that it is terrible since they feel weak, incapable, and humiliated. A young mother described her experience as:

"Some people say: "oh, this (child) is sick; don't tell him anything!" ... It really pisses me off, and I tell them, "What's wrong with him? Every kid gets sick..." [p10].

Participant 4 shared her experience as follows:

"Some people see my son and say, "oh, poor child." It makes me feel really sad ..." [p4].

\section{Blaming parents by acquaintances}

Parents talked about how others assigning blame made them feel guilty about their child's illness. This feeling, in turn, leads to psychological distress in parents. One of the mothers said:

"My mother-in-law always says it is our fault (my husband and me) that he's sick. Crying is the only thing I do and ask what I should do?" [p9].

\section{Peer negative reactions}

According to parents' responses, their child had a body change resulting from a combination of medication side effects. So, their child peer made fun of them and hurt their feelings. A father stated:

“... Taking corticosteroids made her (my daughter) obese... Sometimes, her friends make fun of her, and it really bothers me ..." [p8].

\section{The chronic nature of the disease}

The chronic nature of the disease was one of the inhibiting factors with the following primary concepts: "frequent disease recurrence," "frequent hospitalization," 
"need for constant care," and "invasive treatment and diagnostic procedures."

\section{Frequent disease recurrence}

Frequent recurrence of the disease and restarting medications at higher doses was another concern of the parents. One of the parents said:

“... She takes corticosteroids every day. Her disease gets better for a while. Later, when we try to decrease and stop her medications gradually, again, her disease gets worse ..." [p8].

Another parent described:

"It had been a little more than a year since she was in the hospital. I don't know if she caught a cold or what! Her eyes got swollen again. We took her to the doctor's office, and we are here now." [p14].

\section{Frequent hospitalization}

The child's frequent hospitalizations was another point that parents talked out. One parent stated:

"It's been seven years since my daughter's illness. During this time, I had to hospitalize her again and again." [p3].

\section{Need for constant care}

Some participants complained about feeling exhausted caused by the necessity of constant care for their children. They believed their entire lives were affected by their child's illness. One of the participants shared her experience as follows:

"His school is far from home. I have a hard time. When he is at school, I have to go to school every 3 hours and insert his catheter ..." [p4].

\section{Invasive treatment and diagnostic procedures}

Most parents believe that the procedures performed on children were harsh to bear. Parents talked in this regards as follows:

"I always thought my daughter would be treated with medications ... but when I found out, they had to take her to the operating room and put a catheter in her abdomen (peritoneal dialysis catheter) ... I had a hard time breathing." [p8].

"The doctor told me, "Your son needs to have a biopsy." I said, "What does that mean? "He said that they should take a sample from his kidney when I heard that my world came apart." [p15].

\section{Unfavorable treatment conditions}

The participants mostly complained about improper treatment conditions. This sub-category emerged from the following primary concepts: "lack of medical facilities" and "high treatment costs."

\section{Lack of medical facilities}

Participants discussed how medication shortage, lack of medical facilities, and the imported laboratory test kits delayed a child's treatment process and distressed them. One of the parents described:

"The boy (transplantation donor) had come from Tehran for pre-surgical anesthesia assessment. He was supposed to get a consultation on Tuesday, be hospitalized on Thursday, and undergo the surgery on Saturday. He (laboratory director) said, unfortunately, the solution (necessary for tissue typing test) was not available. I asked what that is. He said the (required) material for this test came from Germany. It is not available now." [p7].

One of the fathers shared his experience as follows:

“... The doctor prescribed some medications for my son. I can't find them anywhere, and I had to go to Turkey to get them. It is unbelievable." [p13].

\section{High treatment costs}

Analyzing the data showed high cost of medications, doctor visits, and frequent hospitalizations impose a huge financial burden on the parents. Participant 10 stated:

"During these years, sometimes my son had been hospitalized for a month. Well, it cost us too much money, and we had a hard time to survive." [p10].

\section{Discussions}

Adaptation is a dynamic process that varies depending on the individuals, situations, and requirements [26]. After analyzing the data, various factors were identified as adaptation barriers and facilitators in parents whose children suffer from CKD. First, we will discuss the factors that facilitate parents' adaptation to their child's chronic disease. Social support was one of the facilitators in adapting the parents of children with CKD. Provision of information and emotional support from medical staff, financial and emotional support of family, teachers' help in preventing the child from falling behind during hospitalization, the cooperation of officials and colleagues in the workplace were among the factors that had a positive effect on parental adaptation. Similar to our findings, the previous studies showed that parents 
who had social support could better adapt to their child's cancer [27-29]. A literature review confirmed that parents who had children with CKD use coping strategies such as social, emotional, and financial support and counseling services from family, friends, school, and medical teams $[10,11,30,31]$.

The participants talked about family capability as a facilitating factor in this study. Parents who have good financial ability, their child is successful in the school, have a good marital relationship, and have similar experiences could adapt to their children's chronic illness more efficiently. They voiced that the existence of family capability increases their hope and tolerance, making it easier for them to adapt to their child's disease. Limited studies have been conducted in this regard. In line with our findings, Wiedebusch et al. reported that parents of children with renal failure used the positive aspects of life as a positive coping strategy [10]. Parents who have a high family income and financial ability make them feel empowered to continue to treat their children despite the high costs [32], a healthy parent's relationship, emotional support of a spouse, a Child success and educational achievements encourage parents and lead them to successful adaptation [31, 33, 34]. These findings are consistent with our results. However, a study by Oskooi et al. showed that past painful experiences could have a positive or negative effect on the adaptation of parents whose children have diabetes [35]. It may depend on the personalities of the individuals. Some can tolerate highlevel crises without experiencing physical and mental problems [36].

Spiritual beliefs were among the facilitating factors indicated by most parents. The parents rescue themselves from anxiety and depression caused by their child's disease through their spiritual beliefs. Similar to our findings, recent studies showed that most parents of children with cancer use spiritual beliefs to adapt emotionally to stressful situations, and they had a better adaptation compared to non-religious ones [29, 37]. Similarly, parents of children with CKD use coping strategies such as religious beliefs to adapt to their child's chronic disease [10]. Thus, spiritual beliefs create hope, motivation, positivity, and emotional support network for parents.

Participants discussed some factors that challenged their adaptation. Family-related barriers were one of the adaptation barriers in this study. Lack of essential information about their child's illness and care and the uncertainty of the prognosis of the child's disease made them confused and concerned about their child's future. In agreement with our results, Pate reported that chronic diseases of children with an unknown prognosis and treatment could disrupt parents' daily activities and threatens the entire family system [38]. In Hutchinson et al. study, uncertainties in the trajectory of cancer have been recognized as a significant obstacle to successful adaptation in the family [39]. Previous studies determined that parents need more information regarding child illness, treatment, diet, and medication to adapt successfully to the stressful situation [11,31, 40]. Thus, medical staff, as an important source of information, can provide the information that parents need to facilitate their adoption. Children's problems, families' financial concerns and limitations caused by the child's chronic disease was another annoying element for parents. They voiced the limitations of the children in social interactions due to special diets and the weakness of their immune system. They also talked about physical complications caused by illness or medications that may socially isolate these children and cause them mental problems like depression. The parents had to restrict their social interactions and family recreation, to prevent complications of the disease. There is limited research on this topic. In consonance with our results, Piran et al. showed that social isolation is more widespread among people who provide care for children with chronic diseases [41]. The Goble study revealed that fathers who take care of children with chronic diseases lose their previous social activities [42]. Children's problems and family restrictions can hurt parents and lead to unsuccessful adaptation.

Mental stress by others was another inhibiting factor in parents' adaptation. The participants mentioned that blaming them or talking about their child by others, and their children's negative peer reactions caused tensions for parents and children. Limited studies have been conducted on this matter. Abedi et al. showed that parents of children with thalassemia experienced a broad range of social and family difficulties after being blamed, unfairly judged, and criticized by acquaintances [43]. These pressures can be a source of mental problems and result in negative adaptation in these parents. Thus, these parents need to receive more emotional and mental support.

The chronic nature of the disease was revealed as one of the barriers to parents' adaptation. Parents experienced mental and physical exhaustion due to the chronic nature of the disease, frequent recurrence, frequent hospitalizations of the child, the need for constant care and the need for invasive diagnosis and treatment. The results of the Yamazaki et al. study in Japan indicated that mothers of children with leukemia had a poor quality of life due to the constant hospitalization of their children [44]. A study conducted by Hutchinson et al. showed that the burden of caring for children with a chronic condition was recognized as one of the biggest obstacles to adaptation of the family [39]. Several recent studies indicated that depression, high blood pressure, anemia, 
repeated infections, fatigue, and failure to thrive were among the prevalent complications of CKD in children with a negative impact on parents' adaptation $[2,45,46]$. Child psychological problems and frequent hospitalizations were the challenges faced by parents of children with CKD and lead to poor family adaptation [30, 31]. Hence, parents need more effort to manage the situation and successfully adapt to challenges [30].

Unfavorable treatment conditions were another obstacle to successful adaptation in these parents. Based on the participants' responses, high treatment costs, especially in low-income families, as well as the lack of medical facilities and having problems accessing medication and other medical services, made life difficult for these families. Recent studies indicated that parents of children suffering from chronic disease might face challenges such as financial burdens $[6,47]$ and difficulties accessing services [6]. The parents who take care of children with chronic diseases spend a lot of money, which may impose high pressure on the families [43]. Moreover, financial problems were serious challenges for the families [48], which can increase stress in the families and hurt their adaptation [35].

\section{Conclusions}

Identifying the factors influencing parental adaptation helps the medical staff to make the necessary interventions to support the parents. According to this study, increasing parent access to the required information, supporting them financially and emotionally, and helping them identify support resources can facilitate their adaptation to their child's chronic illness. Also, identifying and eliminating adaptation barriers can help parents deal better with their child's chronic disease.

\section{Limitations}

This study has some limitations. First, this was the first qualitative study conducted by the researcher. Thus, the researcher obtained guidance from an advisor and colleagues who were experts in qualitative research. Second, the number of fathers who participated in the study was lower than the mother participants. It is because mothers have a significant role in taking care of the child, and also fathers are too busy to stay with the child in the hospital. The authors suggest that intervention studies be designed and implemented based on the results of this study. If the results are confirmed, it can be used to help parents adapt to their child's chronic illness more efficiently. The role of siblings was not investigated in this research. Thus, the authors recommend the role of siblings and its effect on parent adaption to be investigated in future studies.

\section{Supplementary Information}

The online version contains supplementary material available at https://doi. org/10.1186/s12882-020-02170-4.

\section{Additional file 1.}

\section{Abbreviations}

CKD: Chronic kidney disease; FMF: Familial Mediterranean fever

\section{Acknowledgments}

This study is derived from the Ph.D. dissertation in nursing. We want to show our appreciation to the research deputy of Urmia University of Medical Sciences for supporting the research. We would like to thank the participants for their excellent cooperation. We also wish to express our sincere gratitude to Mariam Angelica Parizad and Rosemary Carter for reviewing the

manuscript and writing assistance.

\section{Authors' contributions}

All authors (Fatemeh Khorsandi, Naser Parizad, Masumeh Hemmati MaslakPak, and Aram Feizi) have actively participated in this study. Design of the study FK, MHM, NP, AF; data collection: FK, MHM; analysis and interpretation of data: FK, NP, MHM, AF; manuscript preparation: FK, NP, MHM, AF; manuscript revision: $N P, A F, M H M$. All authors read and approved the final manuscript before submission.

\section{Funding}

This study was supported by Grant from Urmia University of Medical Sciences, Iran. All stages of the study, including the design of the study, collection, analysis, interpretation of data and in writing the manuscript were supported during the study.

\section{Availability of data and materials}

The datasets used and analyzed during the current study are available from the corresponding authors on reasonable request.

\section{Ethics approval and consent to participate}

This study was approved by the research deputy and the ethics committee of Urmia University of Medical Sciences (IR.UMSU.REC.1397.138.). The participants were fully informed about the purpose of the study. Each participant provided written consent prior to participation. They were explained regarding their voluntary nature of participation and that they can stop cooperation at any given time. They also assured about their privacy and confidentiality of their information.

Consent for publication

Written informed consent was obtained from the patient for publication.

\section{Competing interests}

The authors declare no conflicts of interest.

\section{Author details}

${ }^{1}$ Department of Medical - Surgical Nursing, School of Nursing and Midwifery, Urmia University of Medical Sciences, Urmia, IR, Iran. ${ }^{2}$ Patient Safety Research Center, Urmia University of Medical Science, Urmia, IR, Iran. ${ }^{3}$ Department of Management, Psychology, Community, and Fundamental nursing, Urmia, IR, Iran. ${ }^{4}$ Center for Mother and Child Obesity Research Center, Urmia University of Medical Sciences, Urmia, IR, Iran. ${ }^{5}$ Nursing and Midwifery Faculty, Campus Nazlu, 11 KM Road Seru, Urmia, West Azerbaijan 575611-5111, Iran.

Received: 10 March 2020 Accepted: 15 November 2020

Published online: 25 November 2020

\section{References}

1. Hatzmann J, Peek N, Heymans H, Maurice-Stam H, Grootenhuis M. Employment and leisure time of parents. J Child Health Care. 2014;18(4): 346-57 doi: 10.1177\%2F1367493513496668.

2. Sharifian M, Jabbarpour J. Prevalence of chronic kidney disease complication in children admitted Mofid hospital in 2014-2015. Res Med. 2016;39(4):208-12 http://www.pejouhesh.sbmu.ac.ir/article-1-1435-en.pdf. 
3. Geense WW, van Gaal BG, Knoll JL, Maas NM, Kok G, Cornelissen EA, et al. Effect and process evaluation of e-powered parents, a web-based support program for parents of children with a chronic kidney disease: feasibility randomized controlled trial. J Med Internet Res. 2018;20(8):e245. https://doi. org/10.2196/jmir.9547.

4. Cousino MK, Hazen RA. Parenting stress among caregivers of children with chronic illness: a systematic review. J Pediatr Psychol. 2013 Sep 1;38(8):80928. https://doi.org/10.1093/jpepsy/jst049.

5. Wittenberg E, Saada A, Prosser LA. How illness affects family members: a qualitative interview survey. Patient Patient Centered Outcomes Res. 2013; 6(4):257-68. https://doi.org/10.1007/s40271-013-0030-3.

6. Mendenhall AN, Mount K. Parents of children with mental illness: exploring the caregiver experience and caregiver-focused interventions. Fam Soc. 2011;92(2):183-90 doi: 10.1606\%2F1044-3894.4097.

7. Swallow V, Lambert H, Clarke C, Campbell S, Jacoby A. Childhood chronickidney-disease: a longitudinal-qualitative study of families learning to share management early in the trajectory. Patient Educ Couns. 2008 Nov 1;73(2): 354-62. https://doi.org/10.1016/j.pec.2008.07.052.

8. La Clare, Heather L. (2013). The Impact of Childhood Chronic Illness on the Family: Psychosocial Adjustment of Siblings. Retrieved from Sophia, the St. Catherine University repository website:https://sophia.stkate.edu/msw_ papers/218.

9. Smith J, Cheater F, Bekker H. Parents' experiences of living with a child with a long-term condition: a rapid structured review of the literature. Health Expect. 2015 Aug;18(4):452-74. https://doi.org/10.1111/hex.12040.

10. Wiedebusch S, Konrad M, Foppe H, Reichwald-Klugger E, Schaefer F, Schreiber $V$, et al. Health-related quality of life, psychosocial strains, and coping in parents of children with chronic renal failure. Pediatr Nephrol. 2010 Aug 1;25(8):1477-85. https://doi.org/10.1007/s00467-010-1540-z.

11. Geense WW, Van Gaal BG, Knoll JL, Cornelissen EA, van Achterberg T. The support needs of parents having a child with a chronic kidney disease: a focus group study. Child Care Health Dev. 2017;43(6):831-8. https://doi.org/ 10.1111/cch.12476

12. Eccleston C, Fisher E, Law E, Bartlett J, Palermo TM. Psychological interventions for parents of children and adolescents with chronic illness. Cochrane Database Syst Rev. 2015;(4). https://doi.org/10.1002/14651858.CD009660.pub3.

13. Hacialioglu N, Özer N, Erdem N, Erci B. The quality of life of family caregivers of cancer patients in the east of Turkey. Eur J Oncol Nurs. 2010;14(3):211-7. https://doi.org/10.1016/j.ejon.2010.01.017.

14. Modanloo S, Rohani C. Farahani Shirin Abadi a. assessment of family function among parents of children with cancer. Iran J Nurs Res. 2015;10(1): 56-65 http://ijnr.ir/article-1-1481-en.html.

15. Gothwal VK, Bharani S, Reddy SP. Measuring coping in parents of children with disabilities: a rasch model approach. PloS one. 2015;10(3):1-17 doi: 10. 1371\%2Fjournal.pone.0118189.

16. Mussatto K. Adaptation of the child and family to life with a chronic illness. Cardiol Young. 2006;16(3):110-6. https://doi.org/10.1017/ S104795110600103X

17. Yanes T, Humphreys L, Mclnerney-Leo A, Biesecker B. Factors associated with parental adaptation to children with an undiagnosed medical condition. J Genet Couns. 2017 Aug 1;26(4):829-40. https://doi.org/10.1007/ s10897-016-0060-9.

18. de Deuge JK. 'Exploratory study of factors that influence parental adaptation during the autism spectrum disorder diagnostic process', Honours thesis, University of Tasmania. (Doctoral dissertation); 2015.

19. Howells LA. Self-efficacy and diabetes: why is emotional 'Education'Important and how can it be achieved? Hormone Res Paediatr. 2002;57(Suppl. 1):69-71. https://doi.org/10.1159/000053317.

20. Salehitali S, Ahmadi F, Zarea K, Fereidooni-Moghadam M. The role of heath team in coping process of family caregivers with patients under hemodialysis: A qualitative study. Jundishapur J Chronic Dis Care. 2018;7(1). https://doi.org/10.5812/jjcdc.63304.

21. Corbin J, Strauss A. Basics of qualitative research: techniques and procedures for developing grounded theory. 4th ed. Thousand Oaks: SAGE Publications; 2014

22. Gannoni AF, Shute RH. Parental and child perspectives on adaptation to childhood chronic illness: a qualitative study. Clin Child Psychol Psychiatry. 2010;15(1):39-53. https://doi.org/10.1177/1359104509338432.

23. Cleary $M$, Horsfall J, Hayter M. Data collection and sampling in qualitative research: does size matter? J Adv Nurs. 2014;70(3):473-5. https://doi.org/10. 1111/jan.12163.
24. Graneheim UH, Lundman B. Qualitative content analysis in nursing research: concepts, procedures and measures to achieve trustworthiness. Nurse Educ Today. 2004;24:105-12. https://doi.org/10.1016/j.nedt.2003.10.001.

25. Guba EG, Lincoln YS. Epistemological and methodological bases of naturalistic inquiry. ECTJ. 1982;30(4):233-52. https://doi.org/10.1007/ BF02765185.

26. Hildenbrand AK, Barakat LP, Alderfer MA, Marsac ML. Coping and coping assistance among children with sickle cell disease and their parents. J Pediatr Hematol Oncol. 2015;37(1):25 doi: 10.1097\%2FMPH. 0000000000000092

27. Rini C, Manne S, DuHamel K, Austin J, Ostroff J, Boulad F, et al. Social support from family and friends as a buffer of low spousal support among mothers of critically ill children: a multilevel modeling approach. Health Psychol. 2008 Sep;27(5):593. https://doi.org/10.1037/0278-6133.27.5.593.

28. Fletcher PC. My child has cancer: finding the silver lining in every mother's nightmare. Issues Comprehensive Pediatr Nurs. 2011;34(1):40-55. https://doi. org/10.3109/01460862.2011.557905.

29. Pirbodaghi M, Rasouli M, Ilkhani M, Alavi MH. An investigation of factors associated adaptation of mothers to disease of child with cancer based on roy model testing. Qom Univ Med Sci J. 2016;9(11):41-50.

30. Zhang $Y$, Wei $M$, Shen $N$, Zhang Y. Identifying factors related to family management during the coping process of families with childhood chronic conditions: a multi-site study. J Pediatr Nurs. 2015 Jan 1;30(1):160-73. https://doi.org/10.1016/j.pedn.2014.10.002.

31. Tong A, Lowe A, Sainsbury P, Craig JC. Parental perspectives on caring for a child with chronic kidney disease: an in-depth interview study. Child Care Health Dev. 2010 Jul;36(4):549-57. https:/doi.org/10.1111/j.1365-2214.2010.01067x.

32. Gheibizadeh M, Gholami Z, Bassaknejad S, Cheraghian B. Coping strategies of parents with chronic ill children hospitalized in educational hospitals, Ahvaz-Iran. Int J ediatrics. 2017;5(10):5813-25 http://eprints.mums.ac.ir/475/.

33. Rao PA, Beidel DC. The impact of children with high-functioning autism on parental stress, sibling adjustment, and family functioning. Behav Modif. 2009;33(4):437-51. https://doi.org/10.1177/0145445509336427.

34. Bradshaw SR, Shaw K, Bem D, Cummins C. Improving health, well-being and parenting skills in parents of children with medical complexity: a scoping review protocol. BMJ Open 2017 Sep 1;7(9):e015242.doi: https://doi. org/10.1136/bmjopen-2016-015242.

35. Oskouie F, Mehrdad N, Ebrahimi H. Mediating factors of coping process in parents of children with type 1 diabetes. J Diabetes Metabolic Disorders. 2013;12(1):20 http://www.jdmdonline.com/content/12/1/20.

36. Beasley $M$, Thompson $T$, Davidson J. Resilience in response to life stress: the effects of coping style and cognitive hardiness. Personal Individ Differ. 2003. 34(1):77-95. https://doi.org/10.1016/S0191-8869(02)00027-2.

37. Broger B, Zeni MB. Fathers' coping mechanisms related to parenting a chronically ill child: implications for advanced practice nurses. J Pediatr Health Care. 2011 Mar 1;25(2):96-104. https://doi.org/10.1016/j.pedhc.2009.09.004.

38. Pate T. Families of children with chronic illness and the relational family model. The person and the challenges. J Theol Educ Canon Law Soc Stud Inspired by Pope John Paul II. 2016;6(2):57-65.

39. Hutchinson KC, Willard WW, Hardy KK, Bonner MJ. Adjustment of caregivers of pediatric patients with brain tumors: a cross-sectional analysis. PsychoOncology. 2009;18(5):515-23. https://doi.org/10.1002/pon.1421.

40. Swallow V, Knafl K, Sanatacroce S, Hall A, Smith T, Campbell M, Webb NJ. The online parent information and support project, meeting parents' information and support needs for home-based management of childhood chronic kidney disease: research protocol. J Adv Nurs. 2012;68(9):2095-102. https://doi.org/10.1111/j.1365-2648.2011.05908.x.

41. Piran P, Khademi Z, Tayari N, Mansouri N. Caregiving burden of children with chronic diseases. Electronic Physician. 2017;9(9):5380-7. https://doi.org/ $10.19082 / 5380$.

42. Goble LA. The impact of a child's chronic illness on fathers. Issues Compr Pediatr Nurs. 2004;27(3):153-62. https://doi.org/10.1080/01460860490497787.

43. Abedi HA, Ghavimi S, Karimollahi M, Ghavimi E. Lack of support in the life of parents of children with thalassemia. J Health Care. 2014;16(1):40-8.

44. Yamazaki S, Sokejima S, Mizoue T, Eboshida A, Fukuhara S. Health-related quality of life of mothers of children with leukemia in Japan. Qual Life Res. 2005 May 1;14(4):1079-85. https://doi.org/10.1007/s11136-004-3288-z.

45. Kogon AJ, Vander Stoep A, Weiss NS, Smith J, Flynn JT, McCauley E. Depression and its associated factors in pediatric chronic kidney disease. Pediatr Nephrol. 2013 Sep 1;28(9):1855-61. https://doi.org/10.1007/s00467013-2497-5 
46. Becherucci F, Roperto RM, Materassi M, Romagnani P. Chronic kidney disease in children. Clin Kidney J. 2016 Jun 5;9(4):583-91. https://doi.org/10. 1093/ckj/sfw047.

47. Medway M, Tong A, Craig JC, Kim S, Mackie F, McTaggart S, et al. Parental perspectives on the financial impact of caring for a child with CKD. Am J Kidney Dis. 2015 Mar 1;65(3):384-93. https:/doi.org/10.1053/.jajkd.2014.07.019.

48. Klankaradi K. Never-ending caring: The experiences of caring for a child with cerebral palsy. A thesis presented in fulfillment of the requirements for the degree of Doctor of Philosophy in Nursing at Massey University Palmerston North New Zealand 2008. http://hdl.handle.net/10179/1395.

\section{Publisher's Note}

Springer Nature remains neutral with regard to jurisdictional claims in published maps and institutional affiliations.

Ready to submit your research? Choose BMC and benefit from:

- fast, convenient online submission

- thorough peer review by experienced researchers in your field

- rapid publication on acceptance

- support for research data, including large and complex data types

- gold Open Access which fosters wider collaboration and increased citations

- maximum visibility for your research: over $100 \mathrm{M}$ website views per year

At $\mathrm{BMC}$, research is always in progress.

Learn more biomedcentral.com/submissions 